\title{
THE FUNCTIONS OF CONVERSATIONAL IMPLICATURES IN PRINT ADVERTISING
}

\author{
Muchamad Sholakhuddin Al Fajri \\ Maulana Malik Ibrahim State Islamic University \\ E-mail: m.s.alfajri@gmail.com \\ DOI: http://dx.doi.org/10.17509/bs_jpbsp.v17i1.6953
}

\begin{abstract}
This study aims to examine the use of conversational implicatures(Grice, 1975) in print advertising. It analyses 10 advertisements taken from men and women English and Indonesian Magazines issued in 2016 and 2017. Since advertising is a form of communication between the few (advertisers or company) and the many (public), adverts are supposed to follow the Cooperative Principle and its maxims. However, advertisement designers often do not obey the maxims blatantly or flout the maxims which give rise to an implicature in order to achieve a certain communicative effect. I argue that the application of conversational implicatures in advertisements tends to provide enormous benefits for advertisers or company. The application can perform various functions which eventually make the adverts more effective and persuasive. It could make the adverts more economical or cost-effective, make the ad easy to be remembered, arouse the audience's curiosity, attract and retain attention and make the advertisers able to avoid responsibility to defend the implied claims.
\end{abstract}

Keywords: conversational implicature, advertising, cooperative principle, flouting maxims

FUNGSI-FUNGSI IMPLIKATUR PERCAKAPAN DALAM IKLAN CETAK

\begin{abstract}
Abstrak
Penelitian ini bertujuan untuk menguji penggunaan implikatur percakapan (Grice, 1975) dalam iklan cetak. Data yang dianalisis adalah sepuluh iklan yang diambil dari majalah pria dan wanita berbahasa Inggris dan Indonesia yang terbit pada tahun 2016 dan 2017. Karena iklan adalah bentuk komunikasi antara pengiklan atau perusahaan dengan publik, iklan harus mengikuti teori prinsip kerja sama dan maksim. Namun, untuk mencapai efek komunikatif tertentu,perancang iklan seringkali tidak mematuhi maksim atau mengabaikan maksim yang menimbulkan implikatur. Penelitian ini menunjukkan bahwa penggunaan implikatur percakapan dalam iklan cenderung memberi banyak manfaat bagi pengiklan atau perusahaan. Penggunaannya dapat memenuhi berbagai fungsi yang pada akhirnya membuat iklan menjadi lebih efektif dan persuasif. Iklan pun menjadi lebih ekonomis atau hemat biaya, lebih mudah diingat, membangkitkan keingintahuan penonton, menarik dan mempertahankan perhatian serta membuat pengiklan mampu menghindari tanggung jawab untuk mempertahankan klaim tersirat.
\end{abstract}

Kata kunci: implikatur percakapan, pengiklanan, prinsip kerjasama, pelanggaran maksim 


\section{INTRODUCTION}

Advertising is pervasive in today's world. We can easily find it in any media such as newspapers, magazines, on television, billboards, etc. As Geis (1982) states, advertising is as omnipresent as the air we breathe. We are inevitably bombarded with various advertisements in our daily lives. Given this pervasiveness, it is likely that adverts will be easily ignored by audiences as some features of advertising are unsolicited and invasive, thrust upon the audience without consultation (Cook, 2001, p. 203). Advert designers, therefore, try to employ some tacticsto make ads more persuasive and to compete for costumers' attention.

Although an advertisement is composed with verbal and non-verbal communication, language in adverts is considered as a powerful tool to achieve advertising goals. It is the main vehicle to convey messages to consumers and plays a vital role in facilitating people's memory of desirability of products or services (Geis, 1982, p. 23). Similarly, Dyer (1982, p. 111) states that capturing our attention and imagination and assisting memory are probably the chief functions of advertising language. Advertising language thus is frequently exploited by advertisers.

Conversational Implicature, a linguistic technique, is arguably fruitful in assisting advertisers to achieve advertising goals. It has been used by advertisers as extra persuasive or manipulative means (Džanic, 2007) and due to the nature of implicature, it would continue to be an exploited linguistic device in advertising (Pop, 2010).This present study endeavours to explore the functions of conversational implicatures in advertising.It begins with a literature review which describes the idea of implicature and its correlation to advertising language. Then, the data and method will be presented before providing finding and discussion consisting of identifying conversational implicatures and scrutinising their functions in adverts. The last section will present conclusion of this study.

The notion of implicature isfirst introduced by Paul Grice in 1975 in the paper 'Logic and Conversation'. Although it has sustained a number of criticisms, Grice's theory has influenced the development of pragmatics (Levinson, 1983; Thomas, 1995; Cummings, 2005; Huang, 2007). Grice applies the term implicature "to account for what a speaker can imply, suggest, or mean, as distinct from what the speaker literally says" (Brown \& Yule, 1983, p. 31). Another scholar describes it as a proposition implied in an utterance ina certain situation,but it is not an entailment of what was actually said (Gazdar, 1979, 38).In this way, it can be generally stated thatimplicatures are what speakers intend to communicate to their interlocutor beyond what is literally said and entailments of the utterance.

As a matter of fact,Grice distinguishes two classes of implicature: "conventional implicature" and "conversational implicature". Both types of implicature carry an additional level of meaning beyond semantic meanings of the utterance. What makes them different is the way both implicatures consider a context. While in conventional implicature what is implied is always the same irrespective of the context, in conversational implicature the implicature differs depending on the context (Thomas, 1995).However, the focus of this essay is only on conversational implicature. Since conversational implicatures are derived via Grice's theory of Cooperative Principle (Birner, 2013, p. 44), this paper will then firstly discuss the theory.

It is assumed that participants in a conversationtend to be cooperative with each other in order to make an effective exchange. This assumption is considered by Grice (1975, 1989, 2011) as the Cooperative Principle (henceforth, CP). Grice (1975) states "make your conversational contribution such as 
isrequired, at the stage at which it occurs, by the accepted purpose or direction of the talk exchange in which you are engaged" (p.45). Thus, it can be said that people engaged in a conversation will work together by adhering to certain conversational rules to make meaningful interactions. However, it should be noted that Grice's principle does not tell speakers how to interact, but he suggests that people in a conversation always presumes that a set of guidelines is in operation, unless they see contrary indications (Thomas, 1995: p. 62).

Further, Grice (1975) divides the CP into four maxims: quantity; quality; relation and manner. The first maxim is the maxim of quantity, which is related to the amount of information provided by speakers. It suggests that speakers are expected to be as informative as required, providing neither too little nor too much information (Grice, 1975). The next maxim is the maxim of quality. It says that speakers should be sincere and make their contribution truthful and full of evidence (ibid.). The third is themaxim of relation. Speakers are expected to give relevant information to what has been stated before (Cutting, 2008: p. 35) and/or relevant to what happened in the situation (Birner, 2013: p. 54). The last is the maxim of manner. It refers to the clarity of speakers' utterance. Speakers are supposed to say something briefly and orderly and avoid obscurity and ambiguity (Grice, 1975).In short, the CP and its maxims ascertain that in a talk exchange speakers supply sufficient, truthful and relevant information in a clear manner.

In this regard, in the advertisement context, it may suggest that advertisers should give required information (not too little or too much information) about the product, provide information which is true and has adequate evidence about the product, present something which is relevant to the product and avoid providing information which is obscure, ambiguous, and lengthy.
Although the CP and its maxims areassumed to be observed by speakers in a conversation, Grice also acknowledgesthe fact that in some occurrences, people may not adhere to the maxims. He argues that there are four ways where a speaker fails to obey the maxims. Those are clashing a maxim; violating a maxim; opting out a maxim; and flouting a maxim (Grice, 1975).Additionally, Thomas (1995) proposes two other means: infringing a maxim and suspending a maxim. However, among various methods to break the maxims, flouting is the only means that will lead to an implicature (Thomas, 1995).A flout occurs when maxims are not fulfilled in an obvious way with the purpose to make the addressee search for a different or an additional meaning beyond the expressed meaning (Thomas, 1995, p.65).Grundy (2000) points out that flouting maxim is a salient means of making a hearer draw an inference and therefore recover an implicature. The additional meaning which is generated from flouting the maxims is what Grice calls 'conversational implicature'.

Several scholars have defined conversational implicature in various ways. Mey (1993, p. 45) simply states that a conversational implicature is something that is implied in a conversational interaction. It is not explicitly stated in an utterance but it is implied in a text according to a context. For example, when a teacher in a class states "it is noisy outside" while the door of the class is open, it does not explicitly ask a student sitting near to the door to close it, but this meaning is communicated implicitly by the speaker's utterance in that particular context. Moreover, Kempson (1977, p.70) defines conversational implicatures as "assumptions beyond the meaning of the sentences used which the speaker knows and intends that the hearer will make[...] in order to interpret the speaker's sentence in accordance with the cooperative principle". In this way, it can be seen that conversational implicature is an 
additional meaning beyond what is literally said which is derived from assuming that the participants in a conversation adhere to the CP. For example,

\section{A: Have you ever seen snowfall?}

B: My country only has summer and rainy seasons.

In this example, on the surface B says something which is obviously less informative and irrelevant to the A's question. Thus, B has ostentatiously flouted the maxim of quantity and relation. If $\mathrm{B}$ follows the maxims, the answer should be "yes" or "no". Therefore, A must draw an inference to preserve the assumption of B's cooperation. Given the shared knowledge that snow is mostly seen in winter season, the inference that is likely be drawn is that " $\mathrm{B}$ has never seen snowfall".

It should be noted, however, Grice's theory appears not to discuss a systematic process how the hearer calculates and then arrives at the intended one.In some circumstances, when the utterance has some possible implicatures, it could be difficult to determine which one is the intended implicature. It can be because sometimes speakers may convey more than one implicatureon purpose. In this case, Grice's theoryseems not to discuss this situation.

Since advertising is a form of communication between the few (advertisers or company) and the many (public) (Dyer, 1982), it can be said that adverts are supposed to follow the $\mathrm{CP}$ and its maxims in order to make an effective interaction. However, advertisement designers often do not obey the maxims blatantly or flout the maxims which give rise to an implicaturein order to achieve a certain communicative effect.

Pop(2010)assertsthatcommunication in advertising is dependant significantly on implicatures that assist to proceed towards ultimate interpretations by involving the reader in a process of inference-drawing. By involving the addressee in the advertisements, advertisers allow the ads more persuasive rather than of open statements (Geis, 1982: p. 50) and make the audience's attention retained for longer (Tanaka, 1994: p. 94). Moreover,implicatures will enable advertisersto conveycertain claimswhile unnecessarily defending them overtly. Geis(1982) in his own words states as follows:

It should be clear by now why the use of indirect means to convey claims is so attractive to advertisers (and other speakers as well): One doesn't have to defend such claims and consumers are less likely to defend against them than overtly made claims. There is another motivation for employing conversational implicatures. Since they have to be "worked out" by the listener, the listener may find them to be more persuasive than asserted claims(Geis 1982: p. 50).

\section{METHOD}

The data of this present study aretexts selected from print advertisements. There are 10 adverts which areextracted from the latest issue ofboth men and women English magazines (December 2016- January 2017) and Indonesian magazines and tabloids in the last three months which have various topics. The reasons for selecting the data are thatimplicature can be applied in any language (Grice, 1975, 1989, 2011) and the richness of types and topics can help generalize the results of this study.

This study employs qualitative and descriptive methods. Words, phrases and sentences in the adverts are analysed based on the Grice's theory of conversational implicature. The texts are firstly examined on the basis of Grice's maxims to know what maxim(s) is/are flouted in order to recoveran implicature before calculating intended implicatures and then explaining their functions in advertising. 


\section{FINDINGS AND DISCUSSION}

This section is devoted to providing the analysis of the advertisements. The focus is on the identification of implicatures hidden in the advertisements and the description of their functions.

\section{Identification of implicatures in the advertisements}

1. Advert 1

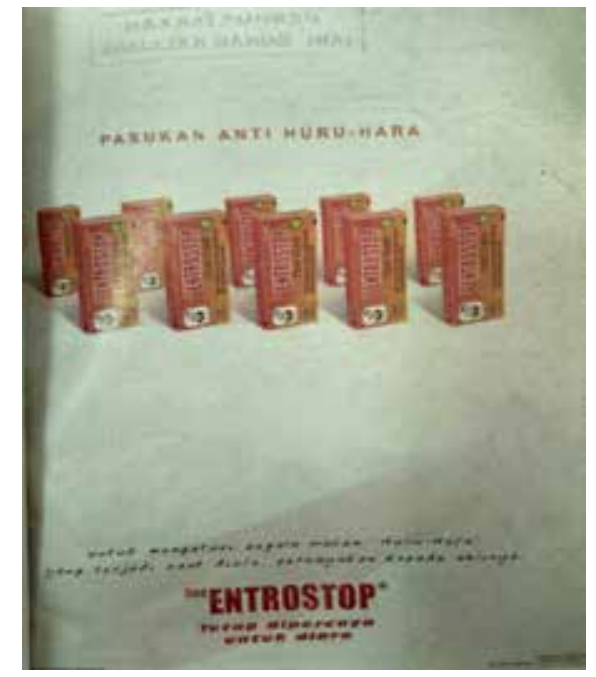

Figure 1: Neo Entrostop Advertisement

(1) Pasukan Anti Huru-Hara

TroopsAntichaos

(1.1) Riot Police

(2) Untuk mengatasi segala macam huru-hara yang terjadi saat diare

To treat all kinds chaos that occur when diarrhea

(2.2) to treat all kinds of chaos that occur when suffering from diarrhea

This is an advertisement of "Neo Entrostop", a brand of medicine for diarrhea. The phrase "Riot Police" and the word "chaos" in this context blatantly flout the maxim of quality. As stated in section 2.2 speakers are not expected to say something false but here the advertiser says something that cannot be true with the application of metaphor. Using metaphor is one of the ways that a speaker can apply to flout the maxim of quality (Cutting, 2008: p. 36). In this case, the symptoms of diarrhea are metaphorically expressed as chaos and the product as riot police. Thus, assuming cooperation the reader should infer an additional meaning of the utterance. By expressing the symptoms of diarrhea as chaos, it might be inferred that the symptoms are not trivial and can be uncontrolled. Additionally, it is likely that by stating the product as riot police the advertiser attempts to indicate that the product is specifically designed to solve the problems caused by diarrhea as riot police who are particularly deployed to confront chaos. 


\section{Advert 2}

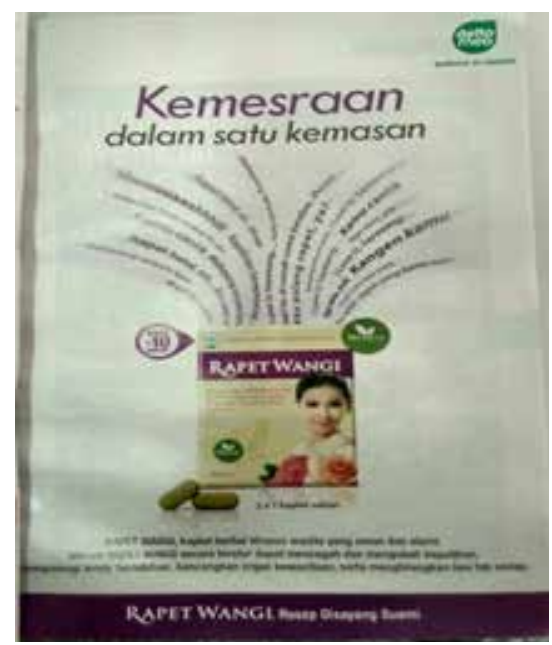

Figure 2: Rapet Wangi Advertisement

(3) Kemesraan dalam satuk emasan

Intimacy in one package

(3.1) Intimacy is in one package

Here is an advert of 'Rapet Wangi' which is an herbal caplet to prevent and treat vaginal discharge and odor. This advertblatantly flouts the maxim of quality. It flouts the maxim of quality in the sense that the sentence (3.1) is obviously false. They are the caplets that are in the package, not intimacy. It also can be seen that the ad flouts the maxim of relation since on the level of what is said there is no direct relation between the sentence and the product. This will lead the reader to infer what the advertiser actually intends to convey. The reader may begin to think why the advertiser uses intimacy as a metaphor for the product by accessing the background knowledge of the product, in correlation with intimacy. Since the benefit of the product is to treat some vaginal problems which can be related to sex, the intended implicature that can be generated might be that the vaginal problems such as vaginal discharge and odor can destroy intimacy with your spouse or partner so that by using the product it will not only treat your vaginal problems but also create and maintain intimacy in your sexual relationship. 
3. Advert 3

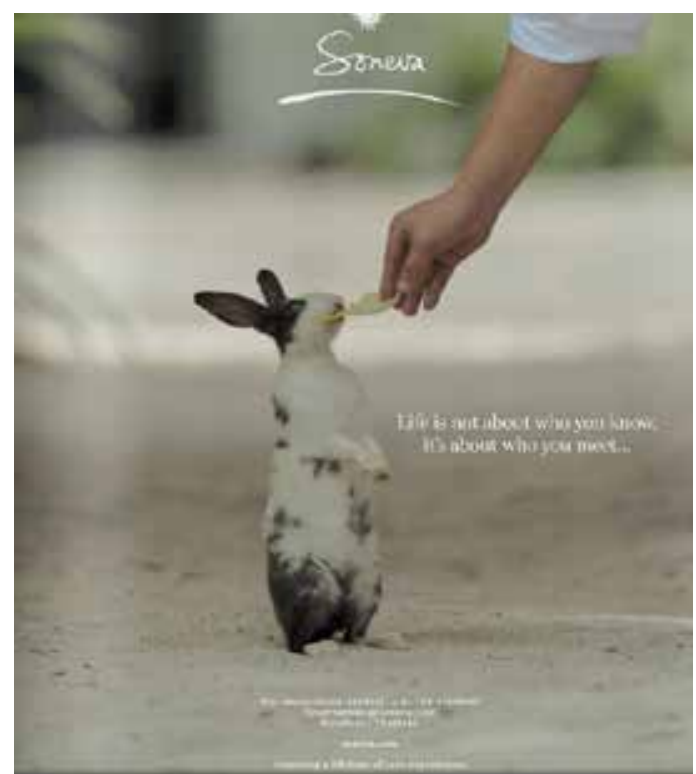

Figure 3: Soneva advertisement

(4) Life is not about who you know, it's about who you meet

This ad is by 'Soneva' which is a brand of is not meaningful if you only know people 'castaway' resorts in the Maldives and outside without ever meeting them, so Thai. It appears that the quantity and go travel and meet them. In this way, the relationmaxims are being flouted in advertiser seems to imply more specifically this advertisement. The sentence (4) is that the reader should go to the resorts in uninformative and irrelevant to the brand. the Maldives and Thai and meet many new Considering the context, the company may people and experience new environment in want to deliver an implied messagethat life order to feel real life.

4. Advert 4

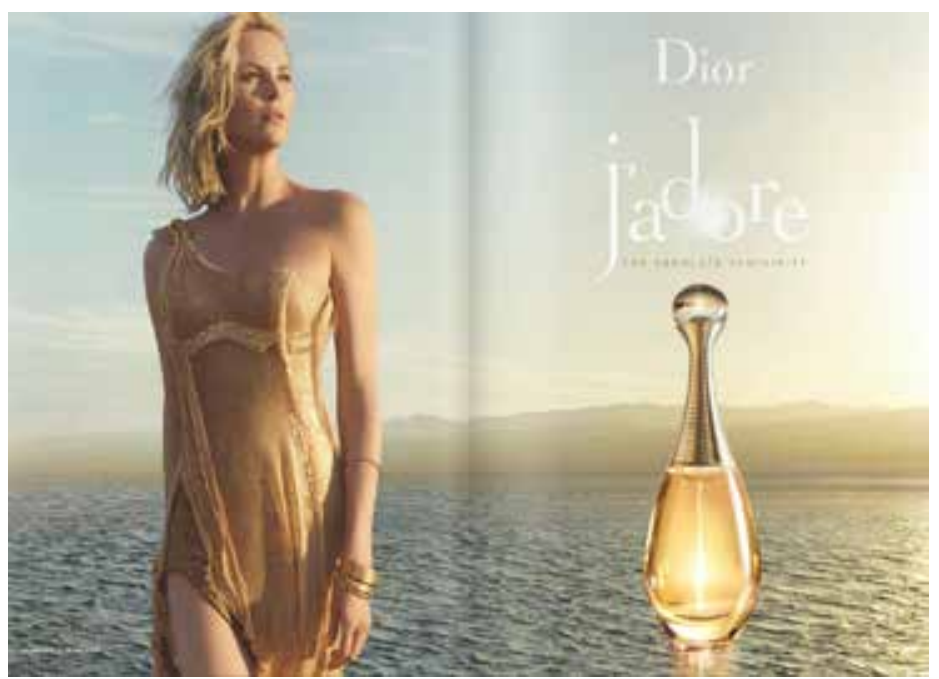

Figure 4: Dior J'adore Advertisement

(5) The absolute femininity 
The advert is by Dior J'adore, which is a brand of perfume. This advert clearly saves a lot of words with only using three words, excluding the name of the product. The information about the features of the product is not sufficiently imparted. The noun phrase (5) is not informative enough and thus it does not fulfil the maxim of quantity. Also, it can be argued that the advert disobeys the maxim of relation as the phrase (5) might not have any direct relation to the features of the product. Thus, since it appears that the advertiser breaks the maxims in a blatant way, the audience will search for additional meanings. The implicit message that the advertiser intends the audience to recover could be that by using the product, you will have the qualities of typical of women or be the absolutely most feminine woman. As stated in the section 2.3, an utterance can potentially have more than one implicature. In this instance, the definite phrase 'The absolute' may trigger the reader to infer another implicature that other brands of perfume do not completely represent femininity. Thus, what is actually the intended implicature of that utterance? It seems that both are the planned implicatures since both implicatures are beneficial for the company and seem not able to be cancelled.

5. Advert 5

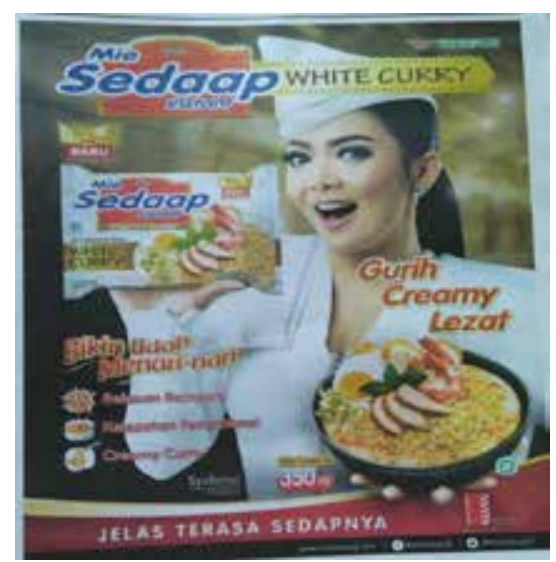

Figure 5: Mie Sedaap Advertisement

(6) Bikin lidah menari-nari

Make tongue dancing

(6.1) Make the tongue dancing

This is an advert of "Mie Sedaap", a brand of an instant noodle. In this advertisement, it is noticeable that the writer flouts the maxim of quality with the employment of personification, assigning human characteristics to an inanimate entity (Ricoeur, 1986, p. 68). The sentence(6.1) is blatantly untruthful and lacks evidence since it is logically unfeasible that a tongue can dance. It thus forces the reader to look for another plausible interpretation, assuming that the advertiser is cooperative. The deductive process might begin by comparing the way people dance with the tongue dancing. Since in this context the product is a kind of food, the strongest comparison that could be worked out is that the graceful movements of our body when dancing with the movement of the tongue when we relishconsuming delicious food. Thus, the implied meaning that can be derived is that the product is really delectable and therefore makes people thoroughly enjoy eating it. 
6. Advert 6

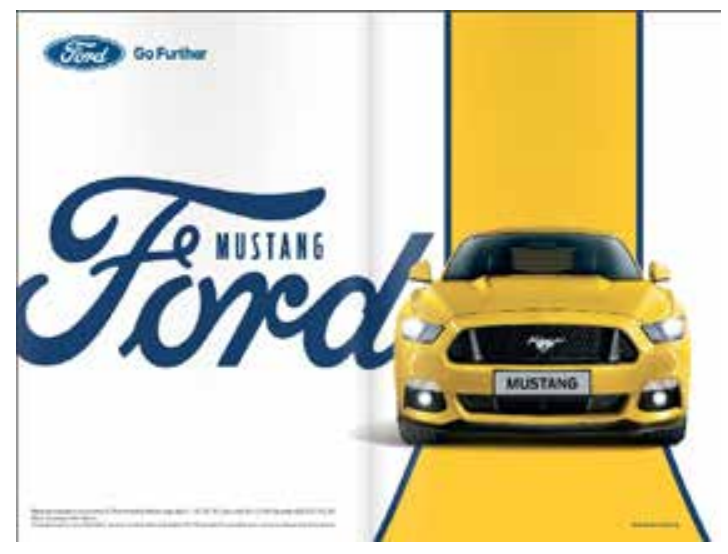

Figure 6: Mustang Ford Advertisement

(7) Go further

The picture is an advertisement of 'Mustang Ford Car'. It can be seen that the company employs limited words in advertising. These are the name of the product and the phrase (7). The phrase, which is also the brand tagline, gives less information about the product and it appears irrelevant. Thus, the maxim of quantity (uninformative) and relation are both flouted. Moreover, it might break the maxim of manner as well since the phrase can have some meanings or can be 7. Advert 7 ambiguous. Assuming cooperation, the audience will look for an additional meaning. In this context, people may infer several implicatures. First, it can be inferred that the Ford car is in a more advanced stage than any other cars or it will bring you further than any other cars. Then, the company may also want to convey that the product is more than what the reader expects from a car. Theseimplicatures seem likely to be expected by the advertiser.

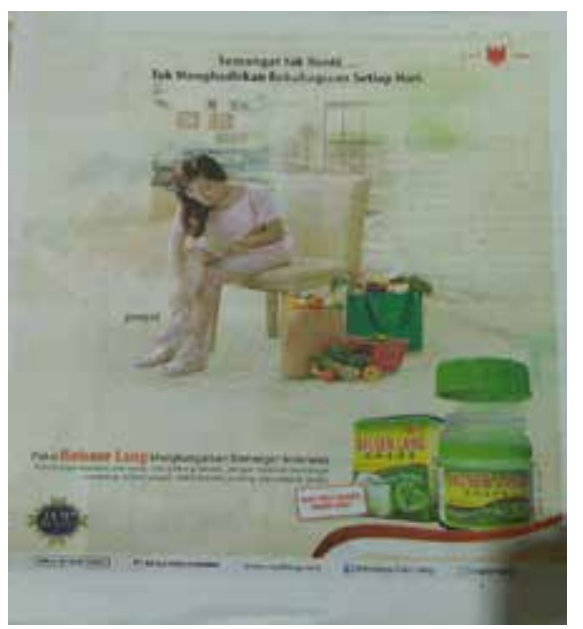

Figure 7: Balsem Lang Advertisement

(8) Semangat tak henti tuk menghadirkan kebahagiaan setiap hari Spirit not stop to present happiness every day

(8.1) Spirit does not stopto bring happiness everyday 
The advert above is the try to convey a message implicitly that advertisement of "Balsam Lang", which is a brand of balm. On the surface, the sentence (8.1) seem sun informative and not to have any direct relation to the product since the general knowledge of balm's function is to treat injuries or reduce pain. It, thus, flouts the maxim of quantity and relation. However, by doing this, the advertiser may weariness and injuries could break your spirit or enthusiasm so that you will not be able to be happy and give out happiness. Therefore, in a such way if you use the product, it will help heal your pain or injuries with the result that they will not avert you from being happy and bringing happiness to other people.

8. Advert 8

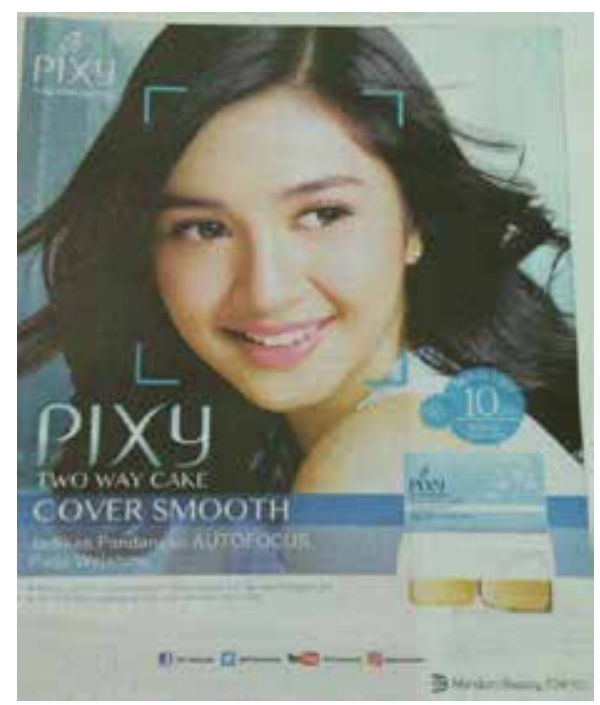

Figure 8: Pixy Two Way Cake Cover Smooth Advertisement

(9) Jadikan pandangan autofocus pada wajahmu

Make gaze autofocus on your face

(9.1) Make (imperative) gazes autofocus on your face

This is an advertisement of "Pixy Two Way Cake Cover Smooth" which is a cosmetic product, face powder. The advert breaks the maxim of quantity (uninformative) and relation. There are no clues and information provided to make the audiences understand what things thatcanmake gazes autofocus on their face and how to do it. Thus, assuming the advertiser's cooperation, the audience will infer that it is the product that will make gazes automatically focus on their face. Additionally, since mostly people's gazes will focus on something that is pleasure for the eyes or enjoyable, the readers will tend to infer that by using the product, their face will be beautiful so that it will attract people's gazes. 
9. Advert 9

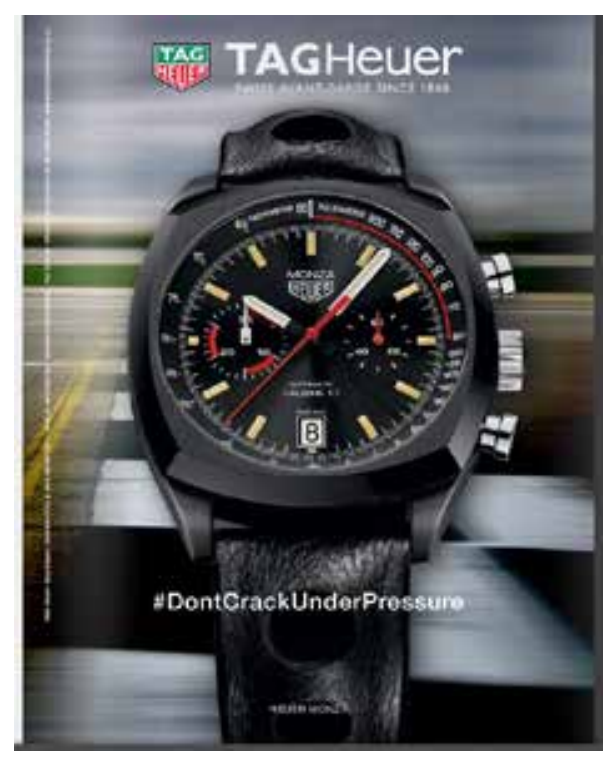

Figure 9: TAG Heuer Advertisement

(10) Don't crack under pressure

This advert is by TAGHeuer, which is a brand name of watch. It appears that the ad flouts several maxims. In relation to the maxim of relation, the sentence (10), which is verbal prohibition, seems not to have any relation to the product. It also could be not too informative as the audience might prefer to know more about the feature of the product. It thus obviously breaks the maxim of quantity and relation. Assuming cooperation, the reader may infer several

inferred that the product is worn by successful people who never give up in a difficult situation but this less likely. Also, the reader may infer that the brand continues to break its limits and never cracks under pressure, such as marketing pressure. Additionally, it may be inferred literally that the product will not be cracked under physical force. All potential implicatures are not likely able to be cancelled and it seems difficult to determine the intended one. implicatures from this advert. It might be 10. Advert 10

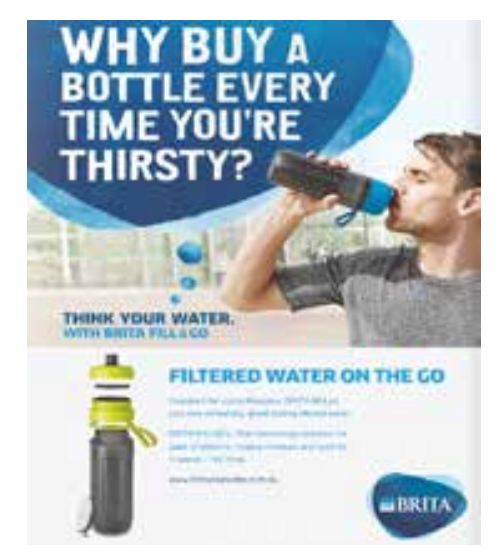

Figure 10: BRITA advertisement

(11) Why buy a bottle every time you're thirsty? 
The advert above is by BRITA, which is a brand of a water filter bottle. Looking at the advert, the interrogative sentence (11)tends to be a rhetorical question which is not sincerely asked by the advertiser.In this context, the advertiser appears not to ask genuinelyyour reasons for always buying a bottle when thirsty. It, therefore, ostentatiouslyflouts the maxim of quality. Geis (1982) states that in advertising,rhetoricalquestions with the interrogative adverb why typically imply "corresponding declarative propositions with the modal verb should". Therefore, an implied meaning of the sentence couldbethat you should not buy a bottle every time you are thirsty.

Havinganalysedall theadvertisements, it can be seen that the advertisers still can reach marketing objectives although they do not fulfil the maxims. Moreover, while it is stated that it is feasible to determine the intended implicature of the utterance, this study shows that sometimes it is difficult to calculate the intended one. It seems that advertisers, in some circumstances, intentionally convey several implicatures to leave the readers in somewhat confusion and may then arouse their curiosity, which is eventually advantageous for the company.

\section{Functions of conversational implicaturein discourse of advertising} Several scholars have asserted that the $u$ se of implicature in advertising is advantageous for advertisers or company (Tanaka, 1994; Geis, 1982; Pop, 2010; Liu, 2012). One of the most beneficial functions is presumably related to the economy of language. This frequently occurs when the writer flouts the maxim of quantity in the sense of providing less information to create an implicature. Advertisers often deliberately give less information than required which leads to an implicature in order to enable them to convey additional information without consuming valuable word space. This strategy inevitably reduces cost for advertising. As Pop (2010: p. 7) points out, conversational implicature is employed in advertising "to make readers draw inferences beyond what was originally stated, and thus sell more meanings at the price of one word". Although advert 4, for instance, uses only few words which make it give less information than required, flouting the maxim of quantity, it still can convey more information and messages to the reader. It still can communicate that 'the perfume will make you have qualities of feminine women' without overtly asserting it.

Besides saving word space, this technique is likely to be valuable for aiding consumers to memorise the product and arousing people's curiosity (Liu, 2012). For example, advertisement 6 only exercises two words which can be easily remembered by the reader and may still achieve promotional goals. This also tends to raise people's desire to know more about the product as the audience may also wonder what the company actually means by 'go further' and then search for more information which my result in trying to purchase the product.

The next function is for attracting and retaining attention. Tanaka (1994) contends that an implicature which allows the audience to be involved in the inferencing process is useful to retain people's attention in the advertisement. This may particularly occur when the maxim of quality (using metaphor) and relation are being flouted. Adverts 1, 2 and 5, for instance, flout the maxim of quality with the employment of metaphor. It appears that the reader might not easily figure out the implied meaning of the advertiser since by using metaphor tends to require more processing effort rather than overt assertions. Similarly, when the information is not relevant to the product, the audience may also need more time to access the intended implicature. Thus, the 
audience presumably will pay attention to the advert longer.

Lastly, the fact that advertisers use implicature to make a claim covertly can give a further advantage. Since implicatures are not explicitly stated, this allows speakers to deny that they intended to convey such meanings (Yule, 1996). Advertisers can avoid the responsibility to defend the claim since the audience is also involved in inferencing the assumption so that it is partly the audience's responsibility. Advertisers do not require to defend inferences drawn by the audience (Geis, 1982) and can, if required, deny that they intend to communicate that assumptions (Tanaka, 1994). For example, advert 2 does not explicitly convey that the product can create intimacy in a sexual relationship and advert 8 does not say that the product will make people beautiful and make gazes autofocus on their face. Also, advert 4 does not state explicitly the claim that other brands of perfume do not completely represent femininity. Thus, If the consumers make complaints about the claims, the advertisers mightbeable to avoid responsibility and may deny that they implied the claims.

\section{CONCLUSION}

This study sought to analyse the use of conversational implicatures in advertising. The results suggest that the employment of implicature stends to provide enormous benefits for advertisers or company. Advertisers do not observe the cooperative principle and its maxims blatantly to create specific effects and achieve promotional goals. It also demonstrates that, in some circumstances, it is difficult to calculate the intended implicature, and advertisers may intend to convey more than one implicature to raise people's curiosity.

Moreover, it has been shown that the application of implicatures can perform various functions in advertisements, which eventually make the adverts more effective and persuasive. It could make the adverts more economical or cost-effective by saving word space, make the ad easyto be remembered by the reader, arouse the audience's curiosity, attract and retain attention and make the advertisers able to avoid responsibility to defend the implied claims.

However, there are still limitations in this paper. The data of this study are very small and limited. Thus, this study may not be able to demonstrate that implicatures are widespread in the discourse of advertising. Moreover, it seems that it would be more convincing if public opinions about the persuasive function ofimplicatures in advertising aretaken into account. Therefore, it could be suggested that the future research couldusealarger number of advertisements and also conduct some interviews with the public about the persuasiveness of advertisements employing implicatures.

\section{ACKNOWLEDGMENTS}

I would like to express my deep gratitude to Dr Claire Hardaker for her valuable feedback on the earlier version of this manuscript, and the anonymous reviewers for their constructive comments. I am also immensely grateful to Indonesia Endowment Fund for Education (LPDP) for funding my study at Lancaster University.

\section{REFERENCES}

Birner, B. J. (2013). Introduction to pragmatics: Chichester, West Sussex, UK : WileyBlackwell.

Brown, G., \& Yule, G. (1983). Discourse analysis. Cambridge: Cambridge University Press.

Cook, G. (2001). The discourse of advertising (2nd ed.). London: Routledge.

Cummings, L. (2005). Pragmatics : a multidisciplinary perspective. Edinburgh: Edinburgh University Press. 
14 Jurnal Pendidikan Bahasa dan Sastra, Volume 17, Nomor 1, April 2017, blm. 1-14

Cutting, J. (2008). Pragmatics and discourse : a resource book for students (2nd ed.). Abingdon: Routledge.

Dyer, G. (1982). Advertising as communication. London \& New York: Routledge.

Gazdar, G. (1979). Pragmatics : implicature, presupposition and logical form. New York: Academic Press.

Geis, M. L. (1982). The language of television advertising. New York: Academic Press.

Grice, H. P. (1975). Logic and Conversation. In P. Cole \& J. L. Morgan (Eds.), Syntax and Semantics 3: Speech Acts (pp. 41-58). New York: Academic Press.

Grice, H. P. (1989). Studies in the way of words. Cambridge, Massachusetts: Harvard University Press.

Grice, H. P. (2011). Logic and Conversation. In D. Archer \& P. Grundy (Eds.), The Pragmatics Reader (pp. 43-54). Abingdon: Routledge.

Grundy, P. (2000). Doing pragmatics (2nd ed. ed.). London: Hodder Arnold.

Huang, Y. (2007). Pragmatics. Oxford: Oxford University Press.
Kempson, R. M. (1977). Semantic theory. Cambridge \& New York: Cambridge University Press.

Levinson, S. C. (1983). Pragmatics. Cambridge: Cambridge University Press.

Levinson, S. C. (2001). Pragmatics: Cambridge: Cambridge University Press.

Liu, F. (2012). A Study of Principle of Conversation in Advertising Language. Theory and Practice in Language Studies, 2(12), 2619-2623. doi:10.4304/tpls.2.12.2619-2623

Mey, J. (1993). Pragmatics : an introduction. Oxford, UK: Blackwell.

Ricoeur, P. (1986). The rule of metaphor: multidisciplinary studies of the creation of meaning in language. London: Routlege.

Tanaka, K. (1999). Advertising language: A pragmatic approach to advertisements in Britain and Japan: Psychology Press.

Thomas, J. (1995). Meaning in interaction : an introduction to pragmatics. London; New York: Longman.

Yule, G. (1996). Pragmatics. Oxford: Oxford University Press. 